\title{
Pengaruh Pendidikan dan Pekerjaan Terhadap Kemiskinan Rumah Tangga dengan Lingkungan Sebagai Variabel Moderating di Kecamatan Bolano Kabupaten Parigi Moutong
}

\author{
Indrawati Indrawati ${ }^{*}$,Ermawati Ermawati ${ }^{2}$, Rabaniyah Istiqamah ${ }^{3}$ \\ ${ }^{1}$ Jurusan Ekonomi Syariah, Fakultas Ekonomi dan Bisnis Islam, IAIN Palu \\ ${ }^{2}$ Jurusan Ekonomi Syariah, Fakultas Ekonomi dan Bisnis Islam, IAIN Palu, \\ ${ }^{3}$ Jurusan Ekonomi Syariah, Fakultas Ekonomi dan Bisnis Islam, IAIN Palu
}

ABSTRAK

Tujuan penelitian ini untuk mengetahui apakah variabel pendidikan, pekerjaan berpengaruh terhadap kemiskinan rumah tangga dan apakah variabel kesehatan lingkungan merupakan variabel modereting. Penelitian ini menggunakan penelitian Kuantitatif dengan Teknik pengumpulan data melalui observasi, wawancara, dan kuesioner. Populasi pada penelitian ini adalah seluruh rumah tangga miskin. Sampel dari penelitian ini berjumlah 95 responden. Teknik pengambilan sampel purposive sampling.Teknik analisis data yang digunakan adalah analisis regresi linear berganda dan analisis residual. Berdasarkan pengolahan data yang telah dilakukan menggunakan SPSS Statistics 21.0 menunjukkan bahwa secara parsial variabel pendidikan berpengaruh positif $(+)$ dan signifikan terhadap kemiskinan rumah tangga dengan besaran pengaruhnya $32,1 \%$, sedangkan variabel pekerjaan berpengaruh negatif (-) dan tidak signifikan dengan besaran pengarunhnya $12,8 \%$, dan secara simultan variabel pekerjaan dan pendidikan berpengaruh terhadap kemiskinan rumah tangga dengan besar pengaruhnya $7,7 \%$. Sedangkan variabel lingkungan bukan sebagai variabel moderating karena pada uji residual tahap pertama $\left(\mathrm{X}_{1}\right)$ dan tahap kedua $\left(\mathrm{X}_{2}\right)$ menunjukkan hasil yang positif pada nilai coefficients beta dan nilai sig >0,05.
INFORMASI

ARTIKEL

Katakunci:

Pendidikan, Pekerjaan,

Kemiskinan Rumah

Tangga, Lingkungan 


\section{PENDAHULUAN}

Kemiskinan merupakan masalah sosial yang bersifat global yang dihadapi setiap bangsa, tidak ada satupun negara di dunia ini yang bebas dari kemiskinan. Kemiskinan merupakan problem kemanusiaan yang menghambat kesejahteraan dan peradaban. Kemiskinan pada hakikatnya menunjuk pada situasi kesengsaraan dan ketidak berdayaan yang dialami seseorang, baik akibat ketidakmampuannya sendiri memenuhi kebutuhan hidup, maupun akibat ketidakmampuan negara atau masyarakat dalam memberikan perlindungan sosial kepada warganya. ${ }^{1}$

Kemiskinan adalah sebuah keadaan yang bersifat multidimensi yang sulit didefinisikan dalam definisi yang bersifat tunggal. Banyak pakar dari beragam disiplin ilmu telah mencoba mendefinisikan keadaan kemiskinan ini.Namun belum ada yang menyepakati definisi kemiskinan ini dalam satu definisi yang disepakati bersama. Perspektif yang digunakan pun beragam, mulai dari perspektif ekonomi, sosiologi, hingga perspektif moralitas. Terlepas dari pro kontrak dan perdebatan mengenai

${ }^{1}$ Edi Suharto, Kemiskinan \& Perlindungan Sosial di Indonesia, Menggagas Model Jaminan Sosial Universitas Bidang Kesehatan.( Bandung : Alfabeta, 2009), 16. keadaan kemiskinan, namun isu kemiskinan tetap menjadi isu yang sangat penting. ${ }^{2}$

Menurut Anggraeni dalam Ali Khomas dkk, kemiskinan merupakan masalah yang kompleks dipengaruhi oleh berbagai faktor yang saling berkaitan, antara lain :tingkat pendapatan, kesehatan, pendidikan, akses terhadap barang dan jasa, lokasi geografis, genderdan kondisi lingkungan. ${ }^{3}$ Mengacu pada Badan Pusat Statistik secara umum kemiskinan didefinisikan sebagai kondisi dimana seseorang atau sekelompok orang tidak mampu memenuhi hak-hak dasarnya untuk mempertahankan dan mengembangkan kehidupan yang bermartabat ${ }^{4}$. Definisi yang sangat luas ini menunjukkan bahwa kemiskinan merupakan masalah multidimensi, sehingga tidak mudah untuk mengukur kemiskinan dan perlu kesepakatan pendekatan pengukuran yang dipakai. ${ }^{5}$

Dalam menjelaskan keadaan kemiskinan, Al-Quran menyebut dengan menggunakan kata faqir danmiskin, terkait dengan definisi fakir dan miskindalam

\footnotetext{
${ }^{2}$ Irfan Syauqi Beik dan Laily Dwi Arsyianti, Ekonomi Pembangunan Syariah, (Jakarta: Raja Grafindo Persada, 2016), 68.

${ }^{3}$ Ali Khomas dkk, Indikator Kemiskinan dan Misklasifikasi Orang Miskin, ( Jakarta : Yayasan Pustaka Obor Indonesia, 2015), 8.

${ }^{4}$ Nurdin, N., Novia, N., Rahman, A., \& Suhada, R. (2019). Potensi Industri Produk Makanan Halal Di Kota Palu. Jurnal Ilmu Ekonomi dan Bisnis Islam, 1(1), 1-12.
}

${ }^{5}$ Badan Pusat Statistik 2015. 
bukuFiqhIslam, defenisi orang miskin adalah orang yang penghasilannya tidak mencukupi untuk memenuhi kebutuhan pokok. Sedangkan fakir adalah mereka yang penghasilannya tak cukup untuk memenuhi separuh dari kebutuhan pokok mereka. ${ }^{6}$

Salah satu sasaran pembangunan nasional adalah menurunkan jumlah penduduk miskin melalui tujuannya yaitu meningkatkan kinerja perekonomian agar mampu menciptakan lapangan kerja dan menata kehidupan yang layak bagi seluruh rakyat yangpada gilirannya akan mewujudkan kesejahteraan penduduk Indonesia.

Maka dengan adanya sasaran pembangunan nasional, pemerintah Indonesia melakukan berbagai upaya baik itu pemerintah pusat maupun daerah, untuk menurunkanangka kemiskinan melalui berbagai program dan kegiatan anti kemiskinan. Program dan kegiatan pengentasan kemiskinan yang dilaksanakan Pemerintah pada saat ini diantaranya adalah: (1) Program Keluarga Harapan (PKH) yaitu program perlindungan sosial melalui pemberian uang non tunai kepada Rumah Tangga Sangat Miskin (RTSM) yang memiliki ibu hamil/nifas/menyusui, dan/atau memiliki anak balita, atau anak usia 5-7 tahun yang belum masuk pendidikan SD,

\footnotetext{
${ }^{6}$ Alim Hasan, Zakat dan Infak:Salah Satu Solusi Mengatasi Problema Sosial di Indonesia,( Kencana Perdana Media Group : 2006), 93.
}

dan/atau memiliki anak usia SD, dan/atau SMP, dan/atau anak usia 15-18 tahun yang belum menyelesaikan pendidikan dasar; (2) Program Raskin (yang sekarang menjadi Rastra/Beras Sejahtera) adalah program subsidi pangan (beras) bagi masyarakat berpendapatan rendah; dan (3) Program Kelompok Usaha Bersama (KUBE) adalah kelompok warga atau keluarga binaan sosial yang dibentuk dan telah dibina melalui Program Kesejahteraan Sosial untuk melaksanakan usaha dalam semangat kebersamaan sebagai sarana untuk meningkatkan taraf kesejahteraan sosial dan Kartu Indonesia Sehat (KIS) adalah kartu yang memiliki fungsi untuk memberikan jaminan kesehatan kepada masyarakat untuk mendapat pelayanan kesehatan secara gratis. $^{7}$

Badan Pusat Statistik mencatat bahwa jumlah penduduk miskin di IndonesiaSeptember 2018 mengalami penurunan dari jumlah 25,95 juta orang menjadi 25,67 juta orang. ${ }^{8}$ Meskipun terjadi penurunan penduduk miskin akan tetapi faktanya masih menunjukkan tingginya jumlah penduduk miskin maupun persentase kemiskinan Indonesia.Hal ini menunjukkan

\footnotetext{
${ }^{7}$ Hermanto, Pengentasan Kemiskinan Di Pedesaan : Pengembangan SDM, Penguatan Usaha, Dan Inovasi Pertanian, Jurnal Penelitian Agro Ekonomi, Vol. 35 No.2, Desember 2017, 140. https://www.researchgate.net>publication. (Diakses 28 Desember 2018).

${ }^{8}$ Badan Pusat Statistik Jakarta Pusat, 2018.
} 
bahwa penanganan yang dilaksanakan pemerintah untuk masyarakat miskin belum mampu untuk menjangkaunya sehingga penanggulangan kemiskinan harus dilakukan secara menyeluruh, yang berarti menyangkut seluruh aspek penyebab kemiskinan.

Salah satu aspek penyebab kemiskinan yang perlu diperhatikan adalah aspek mikro kemiskinan, yang melihat kemiskinan dari sudut individu atau keluarga.Kerangka kerja mengenai perilaku ekonomi rumah tangga miskinjarang sekali dipertimbangkan dalam perumusan berbagai kebijakan pengentasan kemiskinan, karena selama ini kemiskinan sering kali diterjemahkan dengan seberapa dalam kemiskinan itu terjadi dalam suatu komunitas/negara/secara makro.

Banyak faktor yang menyebabkan kemiskinan secara mikro yang dilihat dari keluarga/rumah tangga.Pendidikan dianggap sebagai salah satu faktor penyebab kemiskinan rumah tangga.

Menurut UU No. 20 Tahun 2003 pendidikan adalah :

"usaha sadar dan terencana untuk mewujudkan suasana belajar dan proses pembelajaran agar peserta didik secara aktif mengembangkan potensi dirinya untuk memiliki kekuatan spiritual keagamaan, pengendalian diri, kepribadian, kecerdasan, ahlak mulia, serta keterampilan yang diperlukan dirinya, masyarakat, bangsa dan negara." 9

Pendidikan dan kemiskinan merupakan suatu lingkaran yang salin mempengaruhi.Disatu pihak, perubahan jenjang pendidikan mempengaruhi sekali perkembangan tingkat kemiskinan. Sebaliknya dipihak lain, tingkat kemiskinan itu sendiri berpengaruh pula terhadap perkembangan pendidikan. ${ }^{10} \mathrm{Hal}$ ini dibuktikan dengan hasil sejumlah penelitian yang menunjukkan hasil beragam, seperti penelitian yang dilakukan oleh Yufi Halimah Sa'Diyah menyatakan bahwa variabel pendidikan memiliki pengaruh signifikan positif terhadap kemiskinan rumah tangga. ${ }^{11}$

Faktor lain adalah Pekerjaan, Pekerjaan dalam arti luas didefinisikan sebagai aktifitas utama yang dilakukan oleh manusia, sedangkan definisi pekerjaan dalam arti sempit pekerjaan digunakan untuk suatu tugas / kerja yang menghasilkan uang bagi seseorang. ${ }^{12}$

${ }^{9}$ Republik Indonesia, "Undang-Undang No. 20 Tahun 2003Tentang Sistem Pendidikan Nasional, Bab 1 Pasal 1.

${ }^{10}$ Hendra Esmara, Perencanaan dan Pembangunan di Indonesia, (Jakrta : PT. Gramedia, 1986). 377

${ }^{11}$ Yufi Halaimah Sa'diyah dan Fitrie Arianti, Analisis Kemiskinan Rumah Tangga Melalui FaktorFaktor Yang Mempengaruhnya Di Kecamatan Tugu Kota Serang, Jurnal Ekonomi, Vol. 1 No. 1 Tahun 2012, https://media.neliti.com>publications. (Diakses 28 Desember 2018).

${ }^{12}$ Lia Kurniawati dkk, Hubungan Antara Tingkat Pendidikan dan Status Pekerjaan dengan Usia Perkawinan Pertama Wanita Di Kelurahan 
Pekerjaan juga merupakan faktor yang dapat menyebabkan kemiskinan rumah tangga. Jenis pekerjaan utama dalam rumah tangga merupakan faktor penentu besarnya pendapatan (dan pengeluaran) yang diterima oleh rumah tanga.Hal ini dikarenakan tiap jenis pekerjaan memiliki tingkat upah yang berbeda-beda.penelitian yang dilakukan oleh Nike Roso Wulandarimenyatakan bahwa variabel pekerjaan memiliki pengaruh signifikan terhadap kemiskinan rumah tangga. ${ }^{13}$ Selain itu masih banyak lagi faktor yang dapat mempengaruhi kemiskinan rumah tangga.

Permasalahan kemiskinan di Sulawesi Tengah juga masih menjadi perhatian penting. Sulawesi Tengah pada September tahun 2018 masuk dalam 10 provinsi dan di posisi ke-9 yang angka kemiskinannya masih di atas $10 \%$ yaitu 13,69 \%. Menurut Badan Pusat Statistik Sulwesi Tengah, Provinsi Sulawesi Tengah berada di posisi ke-2 yang masih tinggi angka kemiskinannya di pulau Sulawesi dari tahun 2017 dan 2018. ${ }^{14}$

Kotalama, Kec.Kedungkadang Kota Malang.Jurnal Preventia, Vol. 2 No. 1, 2017.4. http://journal.um.ac.id. (Di Akses desember 2018)

${ }^{13}$ Nike Roso Wulandari, Faktor-Faktor Yang Mempengaruhi Kemiskinan Rumah Tangga Di Kota Kendarai Tahun 2014, Jurnal Progres Ekonomi Pembangunan, Vol. 1 No. 1 Tahun 2016. https://edia.neliti.com>publication. (Diakses 28 Desember 2018). 2017.
Dari uraian latar belakang tersebut, maka dari itu peneliti tertarik melakukan penelitian mengenai"Pengaruh Pendidikan dan Pekerjaan Terhadap Kemiskinan Rumah Tangga dengan Lingkungan Sebagai Variabel Moderating di Kecamatan Bolano Kabupaten Parigi Moutong"

\section{TINJAUAN PUSTAKA}

\subsection{Konsep Dasar Kemiskinan}

Kemiskinan saat ini adalah sebuah keadaan yang bersifat multidimensi yang sulit didefinisikan dalam definisi yang bersifat tunggal. Banyak pakar dari beragam disiplin ilmu telah mencoba mendefinisikan keadaan kemiskinan ini namun belum ada yang menyepakati definisi kemiskinan ini dalam satu definisi yang disepakati bersama. Perspektif yang digunakan pun beragam, mulai dari perspektif ekonomi, sosiologi, hingga perspektif moralitas. Terlepas dari pro kontrak dan perdebatan mengenai keadaan kemiskinan, namun isu kemiskinan tetap menjadi isu yang sangat penting karena diantara tujuan utama pembangunan ekonomi adalah bagaimana mengentaskan kemiskinan dan meminimalisir kesenjangan antara kelompok kaya dengan kelompok miskin. ${ }^{15}$

\footnotetext{
${ }^{15}$ Irfan dan Laily, Ekonomi.68
} 
Menurut Shirazi dan Pramanik dalam Irfan dan Laily, kemiskinan di definisikan sebagai suatu situasi yang dihadapi oleh seorang individu dimana mereka tidak memiliki kecukupan sumber daya untuk memenuhi kebutuhan hidup yang nyaman, baik ditinjau dari sisi ekonomi, sosial, psikologis, maupun ketidakmampuan seseorang dalam memenuhi kebutuhan hidupnya. ${ }^{16}$

Sedangkan menurut Ali Khomas dkk Kemiskinan adalah :

Apabila pendapatan suatu komunitas berada dibawah garis tertentu. Kemiskinan juga berarti kekurangan kebutuhan sosial, termaksud keterkucilan sosial, ketergantungan dan ketidakmampuan untuk berpartisipasi dalam kehidupan masyarakat yang layak. ${ }^{17}$

Dimensi kemiskinan yang dikemukakan oleh Chambers dalam Elvira memberikan penjelasan mengenai bentuk persoalan dalam kemiskinan dan faktorfaktor yang menyebabkan terjadinya kondisi yang disebut kemiskinan. Keadaan kemiskinan tersebut memperluas pandangan ilmu sosial terhadap kemiskinan yang tidak hanya sekedar kondisi ketidakmampuan pendapatan dalam memenuhi kebutuhankebutuhan pokok, akan tetapi juga kondisi ketidakberdayaan sebagai akibat rendahnya kualitas kesehatan dan pendidikan,

\footnotetext{
${ }^{16}$ Ibid. 68

${ }^{17}$ Ali Khomas dkk, Indikator. 2
}

rendahnya perlakuan hukum, kerentanan terhadap tindak kejahatan (kriminal), resiko mendapatkan perlakuan negatif secara politik, dan terutama ketidakberdayaan dalam meningkatkan kualitas kesejahteraannya sendiri. ${ }^{18}$

Dalam pandangan Islam, ketika berbicara mengenai kemiskinan, maka yang ditekankan adalah upayaperhatian, pembelaan dan perlindungan terhadap kelompok miskin yang dilakukan oleh mereka yang terkategorikansebagai kelompok mampu. ${ }^{19}$

Dalam menjelaskan keadaan kemiskinan ini, Al-Quran biasa menggunakan kata faqir dan miskin, terkait dengan definisi fakir miskin, maka ada perbedaan pendapat di antara mazhab Syafii dan Hambali dengan mazhab Hanafi dan Maliki. Menurut mazhab Syafii dan Hambali orang miskin adalah orang yang tidak mampu memenuhi kebutuhan hidup diri dan keluarganya meskipun ia memiliki pekerjaan dan penghasilan.

Adapun definisi fakir dan miskin menurut mazhab Hanafi dan Maliki adalah kebalikan dari definisi mazhab Syafii dan Hambali. Meskin demikian, dari sisipraktik, perbedaan ini tidak terlalu signifikan karena baik fakir maupun miskin, kedua-duannya 
adalah kelompok yang harus dibantu, baik melalui dana zakat, infak maupun shadaqah. ${ }^{20}$

Dalam buku-buku Fiqh Islam, defenisi orang miskin adalah orang yang penghasilannya tidak mencukupi untuk memenuhi kebutuhan pokok.Sedangkan fakir adalah mereka yang penghasilannya tak cukup untuk memenuhi separuh dari kebutuhan pokok mereka. ${ }^{21}$

Islam juga menegaskan bahwa kemiskinan tidak boleh terjadi karena faktor malas. Orang miskin yang malas berusaha sangat dikecam dalam ajaran Islam.Dari pejelasan diatas, dapat di analisi bahwa isu fakir miskin ini tidak bisa terlepas dari konsep pemenuhan kebutuhan minimal. Dalam Islam, definisi kebutuhan pokok ini bukan hanya terkait dengan aspek kebutuhan materiil semata, namun juga terkait dengan kebutuhan spiritual dan beribadah kepada Allah.

Dengan demikian dimensi kebutuhan pokok ini bersifat multidimensi, tidak hanya materiil namun juga spiritual, dan tidak hanya bersifat duniawi, namun juga ukhrawi. Dalam menyusun standar kebutuhan pokok, dan dalam mendefinisikan kemiskinan, maka perhitungan dan standardisasi terhadap kebutuhan minimal ibadah dan spiritual, harus dapat di kalkulasikan dan didefinisikan

\footnotetext{
${ }^{20}$ Irfan dan Laily, Ekonomi. 72

${ }^{21}$ Alim, Zakat dan Infak.93
}

dengan baik. Sehinggan, definisi kemiskinan pun dapat dikembangkan menjadi kemiskinan materiil dan kemiskinan spiritual.

Kemiskinan materiil didasarkan pada ketidakmampuan untuk memenuhi kebutuhan materil sepenuhnya. Kebutuhan materiil ini, seperti sandang, pangan dan papan, harus didefinisikan melalui proses analisis dan survei yang tepat. Sedangkan kemiskinan spiritual didasarkan pada ketidakmampuan untuk memenuhi kebutuhan spiritual minimal, melalui pelaksanaan ibadah yang diwajibkan maupun yang dianjurkan dalam Islam. Ketidakmampuan pemenuhan kebutuhan materiil dan spiritual ini berbeda penyebabnya. ${ }^{22}$

a. Bentuk-Bentuk Kemiskinan

Berdasarkan kondisi kemiskinan yang dipandang sebagai bentuk permasalahan multidimensi, kemiskinan memiliki 4 bentuk seperti berikut $:^{23}$

a) Kemiskinan Absolut

Kemiskinan Absolut adalahsuatu kondisi di mana pendapatan seseorang atau sekelompok orang berada di bawah garis kemiskinan sehingga kurang mencukupi untuk memenuhi kebutuhan standar untuk

\footnotetext{
${ }^{22}$ Irfan dan Laily, Ekonomi. 73-74
}

${ }^{23}$ Criswardan Suryawati, Memahami Kemiskinan Secara Multidimensional, Vol. 8 No. 03 Tahun 2005, https://Jurnal.ugm.ac.id>article>view. (Di Akses 28 Desember 2018). 
pangan, sandang, kesehatan, perumahan, dan pendidikan yang diperlukan untuk meningkatkan kualitas hidup.Garis kemiskinan diartikan sebagai pengeluaran rata-rata atau konsumsi rata-rata untuk kebutuhan pokok berkaitan dengan pemenuhan standar kesejahteraan.Bentuk kemiskinan absolut ini paling banyak dipakai sebagai konsep untuk menentukan atau mendefinisikan kriteria seseorang atau sekelompok orang yang disebut miskin.

b) Kemiskinan Relatif

Kemiskinan Relatif diartikan sebagai bentuk kemiskinan yang terjadi karena adanya pengaruh kebijakan pembangunan yang belum menjangkau ke seluruh lapisan masyarakat sehingga menyebabkan adanya ketimpangan pendapatan atau ketimpangan standar kesejahteraan.Daerah-daerah yang belum terjangkau oleh program-program pembangunan seperti ini umumnya dikenal dengan istilah daerah tertinggal.

c) Kemiskinan Kultural

Kemiskinan Kultural adalah bentuk kemiskinan yang terjadi sebagai akibat adanya sikap dan kebiasaan seseorang atau masyarakat yang umumnya berasal dari budaya atau adat istiadat yang relatif tidak mau untuk memperbaiki taraf hidup dengan tata cara moderen. Kebiasaan seperti ini dapat berupa sikap malas, pemboros atau tidak pernah hemat, kurang kreatif, dan relatif pula bergantung pada pihak lain. d) Kemiskinan Struktural

Kemiskinan Struktural adalah bentuk kemiskinan yang disebabkan karena rendahnya akses terhadap sumber daya yang pada umumnya terjadi pada suatu tatanan sosial budaya ataupun sosial politik yang kurang mendukung adanyapembebasan kemiskinan.Bentuk kemiskinan seperti ini juga terkadang memiliki unsur diskriminatif.

Bentuk kemiskinan struktural adalah bentuk kemiskinan yang paling banyak mendapatkan perhatian di bidang ilmu sosial terutama di kalangan negara-negara pemberi bantuan/pinjaman seperti Bank Dunia, IMF, dan Bank Pembangunan Asia.Bentuk kemiskinan structural juga dianggap paling banyak menimbulkan adanya ketiga bentuk kemiskinan yang telah disebutkan sebelumnya.

b. Jenis-Jenis Kemiskinan

Setelah dikenal bentuk kemiskinan, dikenal pula dengan jenis kemiskinan berdasarkan sifatnya. Adapun jenis kemiskinan berdasarkan sifatnya adalah: ${ }^{24}$

a) Kemiskinan Alamiah

Kemiskinan Alamiah adalah kemiskinan yang terbentuk sebagai akibat adanya kelangkaan sumber daya alam dan minimnya atau ketiadaan pra sarana umum (jalan raya, listrik, dan air bersih), dan keadaan tanah yang kurang subur.Daerah-

\footnotetext{
${ }^{24}$ Elvira, Paulus dan Een, Analisis faktorfaktor. 5
} 
daerah dengan karakteristik tersebut pada umumny adalah daerah yang belum terjangkau oleh kebijakan pembangunan sehingga menjadi daerah tertinggal.

b) Kemiskinan Buatan

Kemiskinan Buatan adalah kemiskinan yang diakibatkan oleh sistem moderenisasi atau pembangunan yang menyebabkan masyarakat tidak memiliki banyak kesempatan untuk menguasai sumber daya, sarana, dan fasilitas ekonomi secara merata.Kemiskinan seperti ini adalah dampak negatif dari pelaksanaan konsep pembangunan (developmentalism) yang umumnya dijalankan di negara-negara sedang berkembang. Sasaran untuk mengejar target pertumbuhan ekonomi tinggi mengakibatkan tidak meratanya pembagian hasil-hasil pembangunan dimana sektor industri misalnya lebih menikmati tingkat keuntungan dibandingkan mereka yang bekerja di sektor pertanian.

c. Penyebab Kemiskinan

Adapun penyebab kemiskinan, menurut Suharto dalam Irfan dan Lailypaling tidak ada 4 penyebab terjadinya kemiskinan yaitu:25

1. Faktor individual yaitu dimana seseorang menjadi miskin karenan faktor pribadinya.

${ }^{25}$ Irfan dan Laily, Ekonomi. 70
2. Faktor sosial dimana kemiskinan terjadi akibat diskriminasi sosial yang dilakukan.

3. Faktor kultural yaitu dimana seseorang menjadi miskin karena perilaku

buruknya.

4. Faktor struktural yaitu dimana kemiskinan terjadi akibat ketidakadilan sistem ekonomi.

Sharp et. All dalam Mudrajat menjelaskan bahwa, penyebab kemiskinan jika dilihat dari sudut pandang ekonomi, antara lain: ${ }^{26}$

1. Secara mikro, kemiskinan muncul karena adanya ketidaksamaan pola kepemilikan sumberdaya yang menimbulkan distribusi pendapatan yang timpang. Pendudukmiskin hanya memiliki sumberdaya dalam jumlah yang terbatas dan kualitasnya rendah.

2. Kemiskinan muncul akibat perbedaan dalam kualitas sumberdaya manusia. Kualitas sumberdaya manusia yang rendah berarti produktivitasnya rendah, yang pada gilirannya upahnya rendah. Rendahnya kualitas sumberdaya ini karena rendahnya pendidikan, nasib yang kurang beruntung, adanya deskriminasi, atau karena keturunan.

3. Kemiskinan muncul akibat perbedaan akses dalammodal.

\footnotetext{
${ }^{26}$ Mudrajat Kuncoro, EkonomiPembangunan : Teori, Masalah, dan Kebijakan, (Yogyakarta : AMP YKPN,2010). 107
} 
Ketiga faktor penyebab kemiskinan yang dikemukakan oleh Sharp, et all bermuara pada teori lingkaran kemiskinan (Vicious Circle of Poverty). Nurkse mengatakan bahwa "a poor country is poor because it is poor" (negara miskin itu miskin karena dia memang miskin). Adanya keterbelakangan, ketidaksempurnaan pasar, dan kurangnya modal menyebabkan rendahnya produktivitas. Rendahnya produktivitas mengakibatkan rendahnya pendapatan yang mereka terima. Rendahnya pendapatan akan berimplikasi pada rendahnya tabungan dan investasi. Rendahnya investasi berakibat pada keterbelakangan.

Dalam perspektif syariah, terjadi perbedaan pendapat yang menjadi penyebab kemiskinan sesungguhnya merupakan sunnatullah fil hayah. Keberadaan kelompok masyarakat yang berbeda-beda penghasilan sesungguhnya tidak bisa dinafikan. Kerena islam tidak perna berbicara bagaimana upaya menghilangkan kemiskinan, akan tetapi berbicara bagaimana mereduksi dan meminimalisir kemiskinan ini agar kehidupan yang lebih sejahtera bisa diraih. Caranya adalah dengan mengembangkan sikap saling menolong, saling membantu, saling bersilaturahim, saling mengisi dan saling bersinergi.

\subsection{Kemiskinan Rumah Tangga}

Istilah rumah tangga dan keluarga sering dicampur adukkan dalam kehidupan sehari-hari.Pengertian rumah tangga lebih mengacu pada sisi ekonomi, sedangkankeluarga lebih mengacu pada hubungan kekerabatan, fungsi sosial dan lain sebagainya.Keluarga didefinisikan sebagai sekumpulan orang yang tinggal dalam satu rumah yang masih mempunyai hubungan kekerabatan/hubungan darah karena perkawinan, kelahiran, adopsi dan lain sebagainya.

Keadaan kemiskinan terkait dengan kemampuan seseorang/rumah tangga untuk memenuhi kebutuhan dasar baik untuk makanan maupun non makanan.Seseorang/ rumah tangga dikatakan miskin bila kehidupannya dalam kondisi serba kekurangan, sehingga tidak mampu memenuhi kebutuhan dasarnya.Batas kebutuhan dasar minimal dinyatakan melalui ukuran garis kemiskinan yang disetarakan dengan jumlah rupiah yang dibutuhkan. ${ }^{27}$

Badan Koordinasi Keluarga Berencana Nasional (BKKBN) dalam Ali Khomas dkk, lebih melihat dari sisi kesejahteraan dibanding dengan dari sisi kemiskinan. Untuk menghitung tingkat kesejahteraan BKKBN melakukan program yang disebut sebagai pendataan keluarga. Pendataan keluarga dilakukan dengan tujuan

\footnotetext{
${ }^{27}$ Elvira, Paulus dan Een, Analisis faktorfaktor. 6
} 
untuk memperoleh data dasar kependudukan dan keluarga dalam rangka program pembangunan dan pengentasan kemiskinan.

Data kemiskinan dilakukan lewat pentahapan keluarga sejahtera dibagi menjadi lima tahap, yaitu $:^{28}$

a. Keluarga Pra Sejahtera (sangat miskin), adalah keluarga yang belum dapat memenuhi salah satu indikator tahapan keluarga sejahtera 1.

b. Keluarga Sejahtera I (miskin), adalah Keluarga yang baru dapat memenuhi indikator-indikator berikut:

a) Pada umumnya anggota keluarga makan dua kali sehari atau lebih.

b) Anggota keluarga memiliki pakaian yang berbeda untuk di rumah, bekerja/sekolah dan bepergian.

c) Rumah yang ditempati keluarga mempunyai atap, lantai, dinding yang baik.

d) Bila anak atau anggota keluarganya yang lain sakit dibawa ke sarana kesehatan.

e) Bila pasangan usia subur ingin ber $\mathrm{KB}$ pergi ke sarana pelayanan kontrasepsi.

f) Semua anak umur 7-15 tahun dalam keluarga bersekolah.

c. Keluarga Sejahtera II, adalah Keluarga yang sudah dapat memeunuhi indikator tahapan keluarga sejahtera 1 dan indikator berikutnya : ${ }^{29}$

\footnotetext{
${ }^{28}$ Ali Khomas dkk, Iindikator. 14-16

${ }^{29}$ Ibid. 14-16
}

a) Pada umumnya Anggota keluarga melaksanakan sesuai agama dan kepercayaan masing-masing.

b) Paling kurang sekali seminggu seluruh anggota keluarga makan daging / ikan / telur.

c) Seluruh anggota keluarga memperoleh paling kurang satu pasang pakaian baru dalam setahun.

d) Luas lantai rumah paling kurang $8 \mathrm{~m}^{2}$ untuk setiap penghuni rumah.

e) Tiga bulan terakhir keluarga dalam keadaan sehat, sehingga dapat melaksanakan tugas / fungsi masingmasing.

f) Ada seorang atau lebih anggota keluarga yang bekerja memperoleh penghasilan.

g) Seluruh anggota keluarga umur 10-60 tahun bisa baca tulis latin.

h) Pasangan usia subur bdengan anak dua atau lebih menggunakan alat / obat kontrasepsi.

d. Keluarga Sejahtera III, adalah keluarga yang sudah memenuhi indikator tahapan keluarga 1 dan indikator keluarga sejahtera 11 dan indikator berikut :

a) Keluarga beruapaya meningkatkan pengetahuan agama.

b) Sebagian penghasilan keluarga ditabung dalam bentuk uang atau barang.

c) Kebiasaan keluarga makan bersama paling kurang seminggu sekali dimanfaatkan untuk berkomunikasi. 
d) Keluarga ikut dalam kegiatan masyarakat di lingkungan tempat tinggal.

e) Keluarga memperoleh informasi dari surat kabar / majalah / radio / tv.

e. Keluarga Sejahtera III Plus, adalah keluarga yang memenuhi indikator tahapan keluarga sejahtera 1 indikator sejahtera 11 , indikator sejahtera 111 dan indikator berikut

a) Keluarga secara teratur dengan suka rela memberikan sumbangan materiil untuk kegiatan sosial.

b) Ada anggota keluarga yang aktif sebagai pengurus perkumpulan sosial

/ yayasan / institusi masyarakat. ${ }^{30}$

Sedangkan Badan Pusat Statistik (BPS) memberikan 14 kriteria yang menjadikan sebagai indikator keluarga miskin sebagai berikut :

a. Luas lantai bangunan tempat tinggal kurang dari $8 \mathrm{~m}^{2}$ per orang.

b. Jenis lantai tempat tinggal terbuat dari tanah / bamboo / kayu murah.

c. Jenis dinding tempat tinggal terbuat dari bamboo/rumbia/kayu berkualitas rendah/tembok tanpa diplester.

d. Tidak memiliki fasilitas buang air besar / bersama-sama dengan rumah tangga lain.

e. Sumber penerangan rumah tangga tidak menggunakan listrik. f. Sumber air minum berasal dari sumur/mata air tidak terlindung/sungai / air hujan.

g. Bahan bakar untuk memasak sehari-hari adalah kayu bakar/arang/minyak tanah.

h. Hanya mengkonsumsi daging/susu/ayam satu kali dalam seminggu.

i. Hanya membeli satu stel pakaian dalam setahun.

j. Hanya sanggup makan sebanyak satu/dua kali dalam sehari.

k. Tidak sanggup membayar biaya pengobatan di puskesmas atau poliklinik

1. Sumber penghasilan kepala rumah tangga adalah petani dengan luas lahan $500 \mathrm{~m}^{2}$, buruh tani, nelayan, buruh bangunan, buruh perkebunan, dan atau pekerja lainnya dengan pendapatan dibawah $\mathrm{Rp}$. $600.000,00$ per bulan.

m. Pendidikan tertinggi kepala rumah tangga adalah tidak sekolah, tidak tamat SD dan hanya SD.

n. Tidak memiliki tabungan/barang yang mudah dijual dengan minimal Rp.500.000, seperti: sepeda motor kredit / non kredit, emas, ternak, kapal motor, atau barang modal lainya. ${ }^{31}$

Berbeda dengan ekonomi Islam garis kemiskinan itu bukan sebatas kebutuhan pangan saja tapi juga termasuk kebutuhan sandang, papan, kesehatan dan pendidikan.

\footnotetext{
${ }^{31}$ Badan Pusat Statistik Jakarta Pusat, 2014
} 
Menurut M. Arif Mufroni para ulama mazhab atau kajian Fiqh Kontemporer indikatorutama yang ditekankan adalah $:^{32}$

a. Indikator ketidakmampuan materi

1. Kemampauan materi nol atau kepemilikan asset nihil (punya/tidak punya apa-apa).

2. Memiliki sejumlah asset properti berupa rumah, barang atau perabot dalam kondisi yang sangat minim.

3. Memiliki aktiva keuangan kurang dari nisab.

4. Memiliki asset selain keuangan namun dengan nilai dibawah nisab.

b. Indikator ketidakmampuan dalam mencari nafkah

1. Tidak mempunyai usaha sama sekali.

2. Mempunyai usaha tapu tidak mencukupi untuk diri dan keluarganya, yaitu penghasilannya tidak memenuhi separuh atau kurang dari kebutuhan.

3. Sanggup bekerja dan mencari nafkah, dan dapat mencukupi dirinya sendiri seperti tukang, pedagang, dan petani. Akan tetapi, kekurangan alat pertukangan atau modal untuk berdagang.

4. Tidak mampu mencari nafkah sebagai akibat dari adanya kekurangan non materi.

\footnotetext{
${ }^{32}$ M.Arif Mufroni, Akuntansi dan Manajemen Zakat, (Kencana Perdana Media Group:2001). 183-185
}

2.3 Faktor-Faktor Yang Mempengaruhi Kemiskinan

a. Pendidikan

Secara etimologi pendidikan berasal dari bahasa yunani yaitu ilmu pendidikan (paedagogiek) dan pendidikan (paedagogie). Paedagogie asal katanya adalah pais yang artinya "anak" dan again, yang terjemahannya "membimbing". Dengan demikian paedagogie berarti "membimbing yang diberikan kepada anak". Istilah paedagogiek lebih menitik beratkan pada teori pendidikan yaitu perenungan tentang pendidikan sedangkan paedagogie menitik beratkan pada masa praktek, yang menyangkut kegiatan belajar mengajar. ${ }^{33}$

Menurut GBHN dalam Junaenah pendidikan secara terminologi adalah usaha sadar untuk mengembangkan kepribadian dan kemampuan di dalam dan diluar sekolah dan berlangsung seumur hidup. ${ }^{34}$

Sedangkan Menurut UU No. 20 Tahun 2003 pendidikan adalah :

"usaha sadar dan terencana untuk mewujudkan suasana belajar dan proses pembelajaran agar peserta didik secara aktif mengembangkan potensi dirinya untuk memiliki kekuatan spiritual keagamaan, pengendalian diri, kepribadian, kecerdasan, ahlak mulia, serta keterampilan yang diperlukan

\footnotetext{
${ }^{33}$ Junaenah Misbah, Pendidikan Islam dalam Perspektif Teori dan Praktek. (Jakarta Selatan : AMP Press Al-Mawardi Prima, 2016). 6-7

${ }^{34}$ Ibid. 10
} 
dirinya, masyarakat, bangsa dan negara." $" 3$

Dalam bahasa Arab pendidikan sering diterjemahkan dengan kata "tarbiyah" dari akar kata rabaa denga kata kerjanya rabbaa. Kata rabbaa diterjemahkan mendidik. Dengan demikian istilah pendidikan berarti bimbingan atau penolong yang diberikan dengan sengaja oleh orang dewasa kepada anak didik agar ia menjadi dewasa. ${ }^{36}$

Menurut Ahmad Tafsir pendidikan dalam Islam adalah

"Bimbingan yang diberikan oleh seseorang kepada seseorang agar ia berkembang secara maksimal sesuai dengan ajaran Islam.”37

Pada dasarnya, pendidikan dalam Islam berupaya mengembangkan seluruh potensi peserta didik seoptimal mungkin, baik yang menyangkut aspek jasmani maupun rohaniah, akal dan akhlak. Dengan optimalisasi seluruh potensi yang dimilikinya, pendidikan Islam berupaya mengantarkan peserta didik kearah kedewasaan pribadi secara paripurna yaitu yang beriman dan berilmu pengetahuan.

${ }^{35}$ Undang-Undang No. 20 Tahun 2003, Tentang Sistem Pendidikan Nasional, Bab 1 Pasal 1

${ }^{36}$ Junaenah, Pendidikan Islam. 8

${ }^{37}$ Ahmad Tafsir, Ilmu Pendidikan dalam Perspektif Islam. ( Bandung : PT Remaja Rosdakarya, 2011). 32
Adapun menurut Al-Ghazali seperti yang dikutip Abidin Ibn Rusn bahwa tujuan pendidikan itu adalah sebagai berikut :

1. Mendekatkan diri kepada Allah yang wujudnya adalah kemampuan dan dengan kesadaran diri dengan melaksanakan ibadah wajib dan sunnah.

2. Menggali dan mengembangkan potensi atau fitrah manusia.

3. Mewujudkan profesionalisasi manusia untuk mengembangkan tugas keduniaan dengan sebaik-baiknya.

4. Membentuk manusia berakhlak mulia, suci jiwanya dari kerendahan budi dan dari safat-sifat tercela.

5. Mengembangkan sifat-sifat manusia yang utama sehingga menjadi manusia yang manusiawi. ${ }^{38}$

Pendidikan dianggap sebagai salah satu faktor yang mampu mengatasi masalah kemiskinan. Baik Adolmon dan Morris, maupun Golbrath dalam Esmara mengemukakan bahwa pendidikan merupakan langkah paling strategis di dalam usaha-usaha mengatasi masalah-masalah kemiskinan. ${ }^{39}$

Peningkatan jenjang pendidikan telah memungkinkan timbulnya perubahan pola pemikiran kearah yang lebih rasional. Proses perubahan pemikiran melalui jenjang

${ }^{38}$ Abidin Ibnu Rush, Pemikiran Al-Ghazali tentang pendidikan Islam (Yogyakarta : Pustaka Pelajar, 1998), 60.

${ }^{39}$ Esmara, Perencanaan. 350 
pendidikan dapat dianggap merupakan proses transisi dari pola kebudayaan lama ke pola kebudayaan baru. ${ }^{40}$

Tingkat pendidikan memiliki dampak yang kuat terhadap kemiskinan.Pada rumah tangga, tingkatpendidikan tertinggi yang dicapai oleh kepala rumah tangga merupakan hal sangat vital.Hal ini dikarenakan pendidikan merupakan salah satu faktor yang mempengaruhi pengahasilan dan kepala rumah tangga merupakan sumber pengahasilan utama dalam rumah tangga.Sehingga pendidikan yang telah ditempuh oleh kepala rumah tangga menjadi faktor yang penting dalam menentukan kesejahteraan rumah tangga.

Jadi pendidikan dan kemiskinan merupakan suatu lingkaran yang salin mempengaruhi.Disatu pihak, perubahan jenjang pendidikan mempengaruhi sekali perkembangan tingkat kemiskinan. Sebaliknya dipihak lain, tingkat kemiskinan itu sendiri berpengaruh pula terhadap perkembangan pendidikan. ${ }^{41}$

b. Pekerjaan

Pekerjaan dalam arti luas didefinisikan sebagai aktifitas utama yang dilakukan oleh manusia, sedangkan definisi pekerjaan dalam arti sempit pekerjaan digunakan untuk suatu tugas / kerja yang menghasilkan uang bagi seseorang. ${ }^{42}$

Menurut Yusuf Al- Qaradhawi

bekerja adalah

"Segala usaha maksimal yang dilakukan manusia, baik llewat gerak anggota tubuh ataupun akal untuk menambah kekayaan, baik dilakukan secara perseorangan ataupun secara kolektif baik untuk pribadi ataupun untuk orang lain (dengan menerima gaji)". 43

Islam memberkati pekerjaan dunia ini dan menjadikannya bagian ibadah dan jihad jika sang pekerja bersikap konsisten terhadap peraturan Allah , suci niatnya, dan tidak melupakan-Nya. Dengan bekerja masyarakat bisa melaksanakan tugas kekhalifahannya, menjaga diri dari maksiat, dan meraih tujuan yang lebih besar. Demikian pula bekerja dengan individu bisa memenuhi kebutuhan hidupnya, mencukupi kebutuhan keluargannya, dan berbuat baik terhadap tetangganya. Semua bentuk yang diberkati agama ini hanya bisa terlaksana dengan memiliki harta dan mendapatkannya dengan bekerja. Maka tidak aneh jika kita menemukan nash-nash Islam yang mengajak umatnya untuk bekerja dan menjadikannya bagian dari ibadah dan jihad. ${ }^{44}$

Pekerjaan dan kemiskinan sangat berkaitan. Jenis pekerjaan utama dalam

\footnotetext{
${ }^{42}$ Lia Kurniawati dkk, Hubungan Antara, 4.

${ }^{43}$ Yusuf Qaradhawi, Norma dan Etika Ekonomi Islam, (Jakarta : Gema Insani, 1997). 88-89

${ }^{44}$ Ibid. 91
}

\footnotetext{
${ }^{40}$ Ibid. 364

${ }^{41}$ Ibid. 377
} 
rumah tangga merupakan faktor yang dapat mempengaruhi kemiskinan rumah tangga dan penentu besarnya pendapatan (dan pengeluaran) yang diterima oleh rumah tangga. Pekerjaan utama kepala rumah tangga sangat berpengaruh terhadap tingkat kemiskinan suatu rumah tangga, hal ini dikarenakan tiap jenis pekerjaan memiliki tingkat upah yang berbeda-beda. Pada sektor pertanian tingkat upah minimum yang akan diterima oleh pekerjanya akan lebih rendah dibandingkan pada sektor lain (seperti : industri) dan di Indonesia mayoritas kepala rumah tangga miskin cenderung bekerja pada sektor pertanian baik dalam sub sektor pertanian tanaman pangan, perkebunan maupun perikanan. ${ }^{45}$

c. Lingkungan

Menurut Umar Fahmi Achmadi Lingkungan adalah

"kondisi atau benda hidup atau benda mati di sekeliling subjek yang didiskusikan. Lingkungan manusia adalah benda-benda, kondisi dan kehidupan di sekitar manusia." ${ }^{46}$

Dalam kehidupan sehari-hari, masyarakat berinteraksi dengan lingkungan baik pemukiman tempat kerja maupun tempat umum dan transportasi. Masing-

${ }^{45}$ Elvira, Paulus, Een,Analisis Faktor-Faktor .8

${ }^{46}$ Umar Fahmi Achmadi, Kesehatan Masyarakat Teori dan Aplikasi, (Jakarta : Rajawali Pers, 2013). 29 masing tempat memiliki persyaratan kesehatan berbeda satu sama lain, mengigat intensitas dan waktu interaksi tidak sama. Komponen lingkungan yang sehari-hari berinteraksi dengan manusia adalah air, udara, dan makanan. Di tempat baik pemukiman, tempat kerja maupun hutan terdapat pula serangga maupun binatang yang memiliki potensi bahaya penyakit, karena mampu menularkan maupun menjadi tempat perkembangbiakan mikroorganisme yang juga menularkan penyakit. Lingkungan yang berpotensi menimbulkan gangguan atau ancaman kesehatan inilah yang menjadi concern para ahli kesehatan lingkungan karena kesehatan lingkungan merupakan inti kesehatan masyarakat. ${ }^{47}$

Menurut Kusnoputranto dalam zafira kesehatan lingkungan adalah suatu usaha untuk mengawasi beberapa faktor lingkungan fisik yang berpengaruh kepada manusia, terutama terhadap hal-hal yang mempunyai efek merusak perkembangan fisik, kesehatan dan daya tahan hidup manusia.

Ruang lingkup dari kesehatan lingkungan meliputi, penyediaan air minum, pengolahan air buangan dan pengendalian pencemaran air, pengelolaan sampah padat, pengendalian vektor penyakit, pencegahan/pengendalian pencemaran tanah, hygiene makanan, pengendalian pencemaran

${ }^{47}$ Ibid. $30-31$ 
udara, pengendalian radiasi, kesehatan kerja, terutama pengendalian dari bahaya-bahaya fisik, kimia dan biologis, pengendalian kebisingan, perumahan dan pemukiman, terutama aspek kesehatan masyarakat dari perumahan penduduk, bangunan-bangunan umum dan institusi, perencanaan daerah dan perkotaan, aspek kesehatan lingkungan dan transportasi udara, laut dan darat, pencegahan kecelakaan, rekreasi umum dan pariwisata, tindakan pencegahan yang diperlukan untuk menjamin agar lingkungan pada umumnya bebas dari resiko gangguan kesehatan serta tindakan-tindakan sanitasi yang berhubungan dengan keadaan epidemi, bencana alam, perpindahan penduduk dan keadaan darurat. ${ }^{48}$

Pada dasarnya, agama Islam mendorong umat manusia untuk menjaga dan memelihara kesehatan karena status derajat kesehatan dipengaruhi oleh 4 faktor, yaitu lingkungan, perilaku, pelayanan kesehatan dan keturunan. Dan faktor kesehatan lingkungan memepunyai pengaruh yang lebih besar terhadap derajat kesehatan.

Terpeliharanya kesehatan adalah satu upaya yang paling penting bagi hidup dan kehidupan manusia. Hasil usaha pemeliharaan kesehatan, tidak hanya terbatas pada terjadinya keadaan sehat, akan tetapi

\footnotetext{
${ }^{48}$ Tengku Hera Zafirah, Pelaksanaan Penyelenggaraan Sanitasi Dasar Di Pasar Tradisional Peringan Di Kota Medan,7-8. https://mid.123dok.com. (Di akses Desember 2018)
}

mempunyai dampak jauh lebih luas pada peningkatan makna hidup dan kehidupan itu sendiri baik perorangan maupun masyarakat, baik aspek duniawi maupun ukhrawi.

\section{Pemeliharaan kesehatan dengan} segala aspeknya adalah amal kebajikan dari setiap amal kebajikan yang didasari iman dikategorikan amal saleh yang akan mendapat balasan berupa kehidupan yang lebih baik. ${ }^{49}$

\subsection{Hipotesis}

Berdasarkan dari rumusan masalah yang di uraikan dalam penelitian ini, maka hipotesis yang dapat di angkat dalam penelitian ini adalah sebagai berikut :

H1: Diduga pendidikanberpengaruh positif dan signifikan terhadap kemiskinan rumah tangga di Kecamatan Bolano Kabupaten Parigi Moutong.

H2: Diduga pekerjaanberpengaruh positif dan signifikan terhadap kemiskinan rumah tangga di Kecamatan Bolano Kabupaten Parigi Moutong.

H3: Diduga dari variabel pendidikan dan pekerjaan ada yang paling berpengaruh terhadap kemiskinan rumah tangga di Kecamatan Bolano Kabupaten Parigi Moutong.

\footnotetext{
${ }^{49}$ Majelis Ulama Indonesi, Air Kebersihan, sanitasi Dan Kesehatan Lingkungan Menurt Agama Islma, ( Jakarta : Sekola Pasca Sarjana Universitas Nasional, 2015). 113
} 
H4: Diduga pendidikan berpengaruh signifikan terhadap kemiskinan rumah tangga bila didorong oleh lingkungan, dan bila lingkungan rendah maka pengaruh positif tidak begitu kuat terhadap kemiskinan rumah tangga di Kecamatan Bolano Kabupaten Parigi Moutong.

H5: Diduga pekerjaan berpengaruh signifikan terhadap kemiskinan rumah tangga bila didorong oleh lingkungan, dan bila lingkungan rendah maka pengaruh positif tidak begitu kuat terhadap kemiskinan rumah tanggadi Kecamatan Bolano Kabupaten Parigi Moutong.

Gambar 1. Model Penelitian

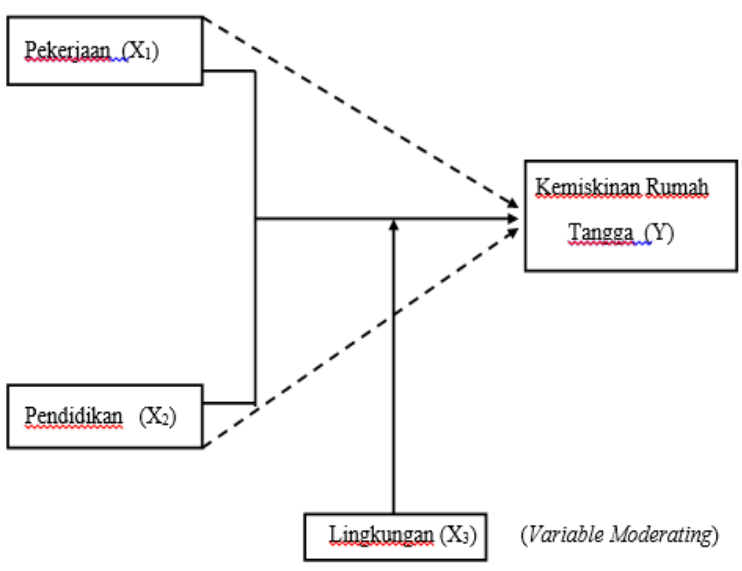

$\longrightarrow=$ Pengaruh secara simultan $----\rightarrow$ = Pengaruh secara Persia

\section{METODE PENELITIAN}

Penelitian ini menggunakan pendekatan kualitatif $^{50}$ dengan pendekatan survey $^{51}$. Kegiatan penelitian meliputi data, analisis, dan interpretasi tetang arti dari data yang diperoleh, instrument penelitian ini menggunakan kuesioner. Penelitian ini juga dimaksud untuk mengetahui pengaruh pendidikan dan pekerjaan terhadap kemiskinan di Kecamatan Bolano Kabupaten Parigi Moutong.

Populasi pada penelitian ini adalah seluruh rumah tangga miskin. Sampel dari penelitian ini berjumlah 95 responden. Teknik pengambilan sampel purposive sampling.Teknik analisis data yang digunakan adalah analisis regresi linear berganda dan analisis residual.

Alat ukur dalam penelitian biasanya dinamakan instrument penelitian. Jadi instrumen penelitian ini adalah suatu alat yang digunakan mengukur fenomena alam maupun sosial yang diamati. ${ }^{52}$ Karena instrumen penelitinan akan digunakan untuk melakukan pengukuran dengan tujuan

\footnotetext{
${ }^{50}$ Miller, K. (2001). Quantitative Research Method in The New Hanbook of Organziational Communication: Advances in Theory, Research and Methods by frederick M. Jablin and Linda L. Putnam (Editors), London : Sage Publications.

${ }^{51}$ Boose, J. H. (1989). A survey of knowledge acquisition techniques and tools. Knowledge Acquisition, 1(1), 3-37. doi: https://doi.org/10.1016/S1042-8143(89)80003-2

${ }^{52}$ Sugiyono, Metode Penelitian Kombinasi, (Bandung: CV Alfabeta, 2015), h.136.
} 
menghasilkan data kuantitatif yang akurat, maka setiap instrumen harus mempunyai skala. Penelitian ini menggunakan skala likert. Data diolah dengan menggunakan aplikasi statistic SPSS.

\section{HASIL DAN PEMBAHASAN}

\subsection{Deskrpsi Responden}

Deskripsi responden digunakan untuk menggambarkan keadaan atau kondisi responden sehingga dapat memberikan informasi tambahan serta memahami hasilhasil penelitian. Penyajian data deskripsi penelitian bertujuan agar dapat dilihat dari data penelitian tersebut serta hubungan anatara variabel yang digunakan dalam penelitian dengan jumlah responden.

a. Deskripsi kuesioner

Penelitian ini dilakukan di kecamatan Bolano kabupaten Parigi Moutong. Data penelitian menggunakan instrumen kuesioner yang dibagikan kepada seluruh rumah tangga miskin yang ada di kecamatan Bolano sebagai sampel penelitian. Penyebaran kuesioner disebarkan oleh peneliti kepada sampel yang diteliti dengan perincian seperti dalam table 1 berikut.

Tabel 1. Deskripsi Kuesioner

\begin{tabular}{|c|c|c|c|}
\hline No & Keterangan & Jumlah & Persentase (\%) \\
\hline 1 & Kuesioner yang disebar & 95 & 100 \\
\hline 2 & Kuesioner yang diolah & 95 & 100 \\
\hline
\end{tabular}

Sumber: hasil penelitian April 2019

b. Deskrpis responden berdasarkan jenis kelamin

Jenis kelamin merupakan perbedaan bentuk, sifat, dan fungsi biologi laki-laki dan perempuan yang menentukan perbedaan peran mereka dalam upaya menyelenggarakan upaya meneruskan garis keturunan. Adapun karakteristik responden berdasarkan jenis kelamin dapat dilihat pada tabel 2 berikut ini :

Tabel 2. Karakteristik Respondent

\begin{tabular}{|c|c|c|c|}
\hline No & Jenis Kelamin & Jumlah (orang) & $\begin{array}{c}\text { Persentase } \\
(\%)\end{array}$ \\
\hline 1 & Laki-Laki & 81 & 84.21 \\
\hline 2 & Perempuan & 14 & 15.79 \\
\hline \multicolumn{2}{|c|}{ Total } & $\mathbf{9 5}$ & $\mathbf{1 0 0}$ \\
\hline
\end{tabular}

Sumber: Olahan Data Primer April 2019

Berdasarkan tabel 1.8, dapat dijelaskan bahwa sebagian besar yang menjadi responden adalah laki-laki yang berjumlah 81 orang dengan persentase sebesar (84.21\%), sedangkan sisanya merupakan responden perempuan berjumlah 14 orang dengan persentase $(15.79 \%)$.

c. Deskrpis responden berdasarkan tingkat usia

Usia yaitu untuk melihat kemampuan fisik dan kesehatan mental spiritual untuk melakukan kegiatan produksi. Tingkat 
kemampuan kerja dari manusia sangat tergantung pada tinggkat umur. Usia yang lebih mudah atau tua cenderung menuju pada kondisi yang belum atau sudah tidak optimal untuk bekerja. Adapun karakteristik responden berdasarkan tingkat umur dapat dilihat pada tabel 3 berikut ini :

Tabel 3. Respondent Menurut Usia

\begin{tabular}{|c|c|c|c|}
\hline No & Usia & $\begin{array}{c}\text { Jumlah } \\
\text { (Orang) }\end{array}$ & $\begin{array}{c}\text { Persentase } \\
(\%)\end{array}$ \\
\hline 1 & $20-29$ & 11 & 11.57 \\
\hline 2 & $30-39$ & 35 & 36.84 \\
\hline 3 & $40-49$ & 21 & 22.11 \\
\hline 4 & $50-59$ & 21 & 22.11 \\
\hline 5 & $60-69$ & 5 & 5.26 \\
\hline 6 & $70-79$ & 2 & 2.11 \\
\hline \multicolumn{2}{|c|}{ Total } & 95 & 100 \\
\hline
\end{tabular}

Sumber: Olahan Data Primer April 2019

Berdasarkan tabel 3 dapat dijelaskan bahwa yang menjadi responden adalah mereka yang mempunyai tingkat kematangan pengalaman dan wawasan yang cukup dalam pengambilan keputusan dan tindakan. Di mana responden yang paling banyak ialah mereka yang masih dalam kategori usia produktif, yakni berusia 20-29 tahun berjumlah 11 orang dengan persentase sebesar (11.57\%), usian 30-39 tahun berjumlah 35 orang dengan persentase sebesar (36.84\%), usia 40-49 tahun berjumlah 21 orang dengan persentase sebesar (21.11\%), usia 50-59 tahun berjumlah 21 orang dengan persentase sebesar $(21.11 \%)$, sedangkan responden yang kategori usia tidak produktif yakni usia 60-69 tahun berjumlah 5 orang dengan persentase sebesar (5.26\%) dan usian 70-79 tahun berjumlah 2 orang dengan persentase sebesar $(2.11 \%)$.

\subsection{Hasil Uji Instrumen}

a. Uji Validitas

Uji validitas yaitu mengkorelasikan masing-masing pernyataan dengan jumlah skor untuk masing-masing variabel. Syarat minimum untuk memenuhi syarat adalah apabila $\mathrm{r}=0,3$ jadi apabila korelasi antar butir dengan skor total kurang dari 0,3 maka instrumen tersebut tidak valid. ${ }^{53}$

Tabel 4. Hasil Uji Validitas

${ }^{53}$ Sugiyono, Metode Penelitian Kuantitatif, Kualitatif dan $R$ an D, (Cet.XIII; Bandung: CV. Alfabeta, 2011), 20. 


\begin{tabular}{|c|c|c|c|c|}
\hline Variabel & $\begin{array}{c}\text { Item } \\
\text { Pernyataan }\end{array}$ & $\begin{array}{c}\text { Corrected } \\
\text { Item Total } \\
\text { Correlation }\end{array}$ & R Kritis & Keterangan \\
\hline Pendidikan & 1 & 0,608 & 0,3 & Valid \\
(X1) & 3 & 0,686 & 0,3 & Valid \\
& 4 & 0,671 & 0,3 & Valid \\
& 5 & 0,456 & 0,3 & Valid \\
Pekerjaan & 1 & 0,636 & 0,3 & Valid \\
(X2) & 2 & 0,694 & 0,3 & Valid \\
& 3 & 0,704 & 0,3 & Valid \\
& 4 & 0,653 & 0,3 & Valid \\
& 1 & 0,703 & 0,3 & Valid \\
Kemiskinan & 2 & 0,324 & 0,3 & Valid \\
Rumah & 3 & 0,501 & 0,3 & Valid \\
Tangga & 4 & 0,524 & 0,3 & Valid \\
(Y) & 5 & 0,462 & 0,3 & Valid \\
& 6 & 0,480 & 0,3 & Valid \\
\hline & 1 & 0,760 & 0,3 & Valid \\
& 2 & 0,743 & 0,3 & Valid \\
Lingkungan & 3 & 0,663 & 0,3 & Valid \\
(M) & 4 & 0,819 & 0,3 & Valid \\
& 5 & 0,801 & 0,3 & Valid \\
\hline Sumber data: Output SPSS 21,0 April 2019 & & \\
& & &
\end{tabular}

Dari tabel 4 menunjukkan bahwa nilai $r_{\text {hitung }}$ pada kolom Corrected Item Total Correlation untuk masing-masing item memiliki $\mathrm{r}_{\text {hitunglebih }}$ besar dan positif dari 0,3 yang artinya item pernyataan dalam variabel $\mathrm{X}$ adalah valid. Pernyataan dalam variabel Y dinyatakan valid dan pernyataan variabel $\mathrm{Z}$ dinyatakan valid. Sehingga pernyataan kuesioner yang dinyatakan valid dapat digunakan dalam pengumpulan data penelitian.

\section{b. Uji Realibilitas}

Realibilitas mengandung pengertian bahwa suatu instrumen dapat dipercaya untuk digunakan sebagai pengumpul data karena instrumen tersebut valid. Instrumen yang valid tidak akan bersifat tandesius mengarahkan responden untuk memilih jawaban-jawaban tertentu.

Instrumen yang sudah dipercaya, yang reliable, akan menghasilkan data yang dapat dipercaya pula. Apabila datanya memang sesuai dengan kenyataanya, maka berapa kalipun diambil tetap akan sama. Alat ukur itu reliabel bila alat itu dalam mengukur suatu gejala pada waktu yang berlainan senantiasa menunjukan hasil yang sama.

Jadi alat yang reliabel secara konsisten memberi hasil ukuran yang sama. Untuk menguji ketepatan atau kepercayaan tersebut yaitu dengan menguji ketepatan antara pertanyaan dengan skor jawaban responden yang dihasilkan. Selanjutnya dilakukan uji statistic yaitu dengan Alpha Cronbach. Suatu variabel dianggap reliabel jika nilai alpha diatas 0,6.

Tabel 5. Hasil Uji Reliabilitas

\begin{tabular}{|c|c|c|c|}
\hline Variabel & $\begin{array}{c}\text { Reliability } \\
\text { Coeficiens }\end{array}$ & $\begin{array}{c}\text { Cronbach } \\
\text { Alpha }\end{array}$ & Keterangan \\
\hline Pendidikan (X1) & 5 Item & 0,803 & Reliabel \\
\hline Pekerjaan (X2) & 4 Item & 0,848 & Reliabel \\
\hline $\begin{array}{c}\text { KemiskinanRumah } \\
\text { Tangga (Y) }\end{array}$ & 6 Item & 0,752 & Reliabel \\
\hline Lingkungan (M) & 5 Item & 0,898 & Reliabel \\
\hline
\end{tabular}

Sumber data; Output SPSS 21,0 April 2019

Tabel 5 di atas dapat diketahui bahwa masing-masing variabel memiliki Cronbach's Alpha $(\alpha)$ lebih dari 0,60 ( $\alpha>$ $0,60)$, yang artinya bahwa semua variabel yaitu X1, X2, X3, X4 dan Y adalah reliabel. 
Dengan demikian pengolahan data dapat dilanjutkan ke jenjang selanjutnya.

c. Deskripsi Variabel Penelitian

Setelah data terkumpul, selanjutnya ialah melakukan tabulasi data untuk melihat tanggapan responden mengenai variabel penelitian yaitu pekerjaan dan pendidikan (variabel independen), kemiskinan rumah tangga (variabel dependen), dan lingkungan(variabel tergantung).

Rumus yang digunakan menurut Sudjana, yaitu $:^{54}$

$$
\mathrm{P}=\frac{\text { Rentang }}{\text { Banyak kelas }}
$$

Dimana :

$$
\mathrm{P} \quad=\text { panjang kelas }
$$

interval

Rentang $=$ data tertinggi data terendah

Banyak kelas $\quad=5$

Berdasarkan rumus tersebut, maka panjang kelas interval adalah :

$$
\mathrm{P}=\stackrel{5-1}{-0,8}
$$

5

Maka interval dari kriteria penelitian rata-rata dapat diinterprestasikan sebagai berikut :

Sangat buruk $=1,00-1,79$

${ }^{54}$ Yogi Iskandar, Pengaruh Kesesuaian Kompensasi terhadap Kinerja Karyawan pada PT. Bentoel Distribusi Utama Cabang Palu (Skripsi IAIN Palu), 54.

$$
\begin{array}{ll}
\text { Buruk } & =1,80-2,59 \\
\text { Cukup baik } & =2,60-3,39 \\
\text { Baik } & =3,40-4,19 \\
\text { Sangat baik } & =4,20-5,00
\end{array}
$$

\subsection{Hasil Analisis Data}

Sebelum metode regresi digunakan dalam pengujian hipotesis, terlebih dahulu model tersebut akan diuji apakah memenuhi asumsi kalsik atau tidak. Uji asumsi klasik adalah persyaratan statistik yang harus dipenuhi pada analisis regresi linear berganda. Asumsi klasik dimaksudkan untuk mengetahui apakah koefisien regresi yang didapatkan telah benar dan dapat diterima serta menghindari kemungkinan adanya pelanggaran asumsi klasik yang merupakan asumsi dasar dalam metode analisis regresi. Hasil uji asumsi klasik disajikan sebagai berikut:

a. Uji Asumsi Klasik

\section{Uji Normalitas}

Uji normalitas bertujuan untuk menguji data yang penelitian yang dilakukan memiliki distribusi yang normal atau tidak. ${ }^{55}$ Model regresi yang baik adalah distribusi data normal atau mendakati normal. Adapun cara untuk mendeteksinya, yaitu dengan analisis grafik.

Analisis grafik merupakan cara untuk melihat normalitas residual yaitu dengan melihat garafik histogram yang

\footnotetext{
${ }^{55}$ Asep dan Baharudidin, Metode, 114.
} 
membandingkan data observasi dengan distribusi yang mendekati distribusi normal. Model lain yang digunakan dalam analisis grafik adalah dengan melihat normal Probability Plot yang membandingkan kumulatif dari distribusi normal. Jika distribusi data residual normal, maka garis yang akan menggambarkan data sesungguhnya akan mengikuti garis diagonalnya. Dengan menggunakan SPSS for Windows versi 21 baru terlihat grafik distribusi normal sebagai berikut:

Gambar 2. Hasil Uji Asumsi Klasik

Normalitas

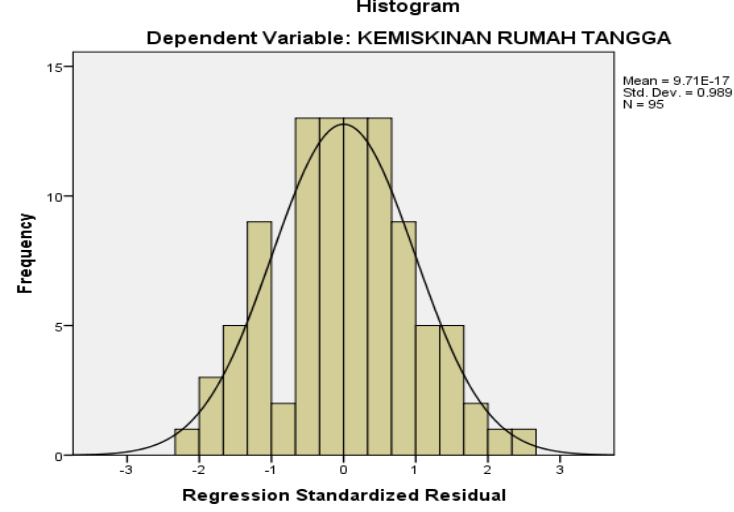

Gambar 2 menunjukkan bahwa data penelitian menunjukkan bentuk normal karena mengikuti bentuk distribusi normal dimana pola distribusi yang normal tidak terjadi kemiringan, sehingga dapat disimpulkan bahwa distribusi data penelitian ini telah memenuhi asumsi normalitas data.
Sedangkan hasil dari grafik Probability Plot (P-Plot) dari program SPSS for Windows Release 21.0 dalah sebagai berikut:

Gambar 3. Hasil Uji Asumsi Klasik Normalitas

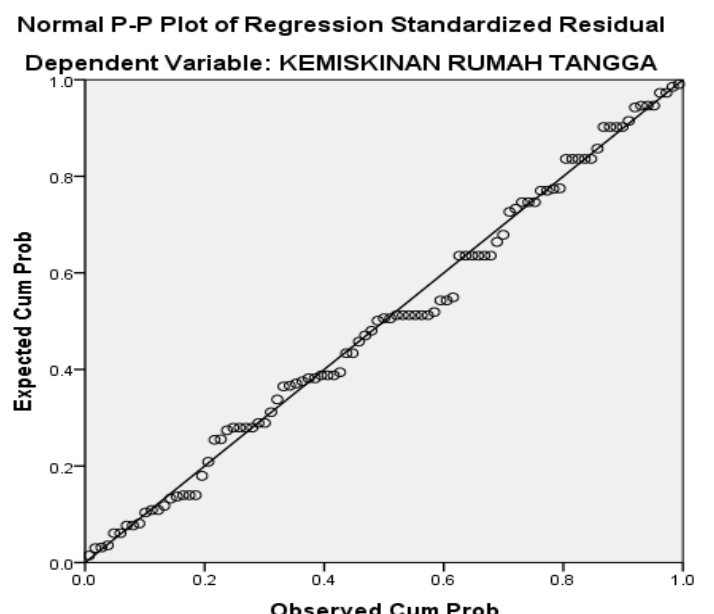

Gambar 3 menunjukkan bahwa terlihat titik titik menyebar disekitar garis diagonal, serta penyebaran mengikuti arah garis diagonal. Maka model regresi layak dipakai. Jika data menyebar disekitar garis diagonal dan mengikuti arah diagonal, maka model regresi memenuhi asumsi normalitas.

\section{Uji Heteroskedastisitas}

Uji heteroskedasitas dilakukan untuk mengetahui apakah dalam model regresi terjadi kesalahan varians dari residual suatu pengamatan ke pengamatan lain, jika varians dari residual dari suatu pengamatan ke pengamatan lain berbeda maka disebut heteroskedasitas. Model regresi terbaik adalah yang tidak terjadi heteroskedasitas.Untuk menguji asumsi ini 
dilakukan dengan melalui garfik scatterplot antara variabel terikat (ZPRED) dan variabel bebas (SRESID).

Gambar 4. Hasil Uji Asumsi Klasik

Heteroskedastisitas

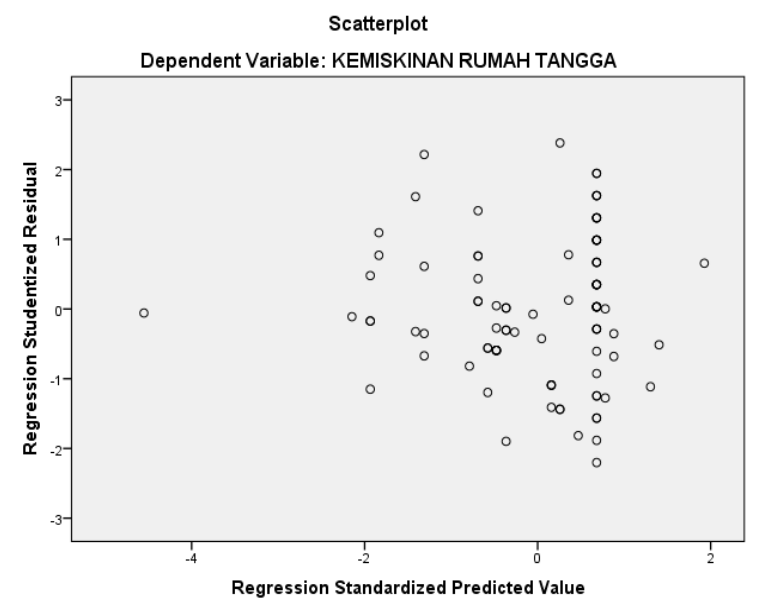

Gambar 4 menunjukkan bahwa titiktitik atau poin-poin menyebar di atas dan di bawah angka 0 dan sumbu Y. sehingga dapat disimpulkan bahwa tidak terjadi heteroskedastisitas pada model regresi atau dengan kata lain terjadi homoskedastisitas.

3. Uji Multikolinieritas

Model yang baik seharusnya tidak terjadi korelasi di antara variabel bebas. Apabila terjadi korelasi antara variabel bebas, maka terdapat problem multikolinieritas pada model regresi tersebut. Untuk mendeteksi ada atau tidaknya multikolinieritas yang tinggi antara variabel independen dapat dideteksi dengan cara melihat nilai tolerance dan variance inflation factor (VIF).

Hasil uji multikolinieritas dapat dilihat pada tabel coefficiebts tepatnya pada colom collinearty statistic. Untuk lebih jelasnya dapat dilihat pada tabel berikut ini:

Tabel 6. Hasil Uji Asumsi Klasik

Multikolinieritas

\begin{tabular}{|c|c|c|c|}
\hline \multirow{2}{*}{ Model } & \multicolumn{2}{|c|}{ Collinearity Statistics } & \multirow{2}{*}{ Keterangan } \\
\hline & Tolerance & VIF & \\
\hline $\begin{array}{c}1 \\
\text { (Constant) }\end{array}$ & 0,739 & 1,353 & Non \\
\hline $\begin{array}{l}\text { Pendidikan } \\
\text { Pekerjan }\end{array}$ & 0,739 & 1,353 & $\begin{array}{l}\text { multikolinieritas } \\
\text { Non } \\
\text { multikolinieritas }\end{array}$ \\
\hline
\end{tabular}

Sumber data: : Output SPSS 21,0 April 2019

Pada tabel 6 menunjukkan bahwa nilai tolerance pada variabel pendidikan dan pekerjaan sama-sama bernilai 0,739 dan VIF bernilai 1,353. Nilai tolerance dari kedua variabel ini lebih dari 0,10 dan nilai VIF dari keduanya kurang dari 10. Sehingga dapat disimpulkan tidak terjadi multikolinieritas pada kedua variabel bebas.

b. Analisi Regresi Berganda

Analisis regresi bergandadigunakan bila bermaksud meramalkan bagaimana keadaan variabel dependen, bila dua atau lebih variabel independen sebagai factor prediktornya. Selanjutnya dari hasil analisis regresi berganda ini akan diketahui ada tidaknya pengaruh secara parsial dan simultan variabel pekerjaan (X1), pendidikan (X2) terhadap Kemiskinan rumah tangga $(\mathrm{Y})$.

Berdasarkan hasil olah data menggunakan SPSS 21.0 for Windows diperoleh hasil analisis regresi berganda sebagai berikut : 
Tabel 7. Hasil Analisis Regresi Berganda

\begin{tabular}{|c|c|c|c|c|c|c|c|c|}
\hline \multicolumn{9}{|c|}{ Coefficients $^{\mathrm{a}}$} \\
\hline \multirow{3}{*}{\multicolumn{2}{|c|}{ Model }} & \multirow{2}{*}{\multicolumn{2}{|c|}{$\begin{array}{c}\text { Unstandardized } \\
\text { Coefficients }\end{array}$}} & \multirow{3}{*}{\begin{tabular}{|c|}
$\begin{array}{c}\text { Standardized } \\
\text { Coefficients }\end{array}$ \\
Beta
\end{tabular}} & \multirow[t]{3}{*}{$\mathrm{T}$} & \multirow[t]{3}{*}{ Sig. } & \multirow{2}{*}{\multicolumn{2}{|c|}{ Collimearity Statistics }} \\
\hline & & & & & & & & \\
\hline & & B & $\begin{array}{l}\text { Std. } \\
\text { Error }\end{array}$ & & & & Tolerance & VIF \\
\hline \multirow{3}{*}{1} & (Constant) & 16.684 & 4.448 & & 3.751 & .000 & & \\
\hline & PENDIDIKAN & .475 & .172 & .321 & 2.754 & .007 & .739 & 1.353 \\
\hline & PEKERJAAN & .282 & .257 &. .128 & -1.098 & .275 & .739 & 1.353 \\
\hline
\end{tabular}

Hasil analisis regresi linear berganda pada tabel 7 di atas, kemudian dimasukkan ke dalam model persamaan regresi berganda sebagai berikut:

$$
\mathrm{Y}=16,684-0,282_{\mathrm{X} 1}+0,475 \mathrm{x} 2
$$

Hasil persamaan regresi tersebut dapat diinterprestasikan sebagai berikut :

a) Nilai koefisien $\beta$ o 16.684, jika kualitas pekerjaan $\left(\mathrm{X}_{1}\right)$ dan pendidikan $\left(\mathrm{X}_{2}\right)$ tidak mengalami perubahan atau konstan, maka memungkinkan terjadi peningkatan kemiskinan sebesar 16.684 .

b) Nilai koefisien $\beta 1=0,475$ bernilai positif $(+)$, hal ini menunjukkan jika terjadi kenaikan pada pendidikan sebesar $1 \%$ maka tingkat kemiskinan rumah tangga juga akan mengalami kenaikan sebesar $0,475 \%$.

c) Nilai koefisien $\beta 2=-0,282$ bernilai negatif (-), hal ini menunjukkan bahwa jika terjadi kenaikan pada pekerjaan sebesar $1 \%$ maka tingkat kemiskinan rumah tangga akan mengalami penurunan sebesar $-0,282 \%$.

c. Analisis Residual

Metode residual yaitu uji residual yang dilakukan dengan meregresikan metoderesidual yaitu uji residual yang dilakukan dengan meregresikan variabel tergantung terhadap nilai mutlak residual dari regresi variabel bebas terhadap variabel yang dihipotesiskan sebagai variabel moderasi.

Hasil perhitungan Persamaan regresi moderasi juga menunjukan bahwa variabel moderasi (lingkungan) memiliki arah positif terhadap variabel dependen (kemiskinan rumah tangga). Hasil perhitungan di atas dapat dijelaskan sebagai berikut :

1. Nilai konstanta sebesar 0,661 menyatakan bahwa jika variabel moderasi yaitu lingkungan tidak tetap atau bernilai positif maka kemiskinan rumah rangga yang dihasilkan akan bernilai 0,661

2. Keofisien regresi variabel sebesar 0,134 dan bertanda positif, sedangkan nilai signya $0,195>0,05$ sehingga dengan ini menyatakan tidak adanya hubungan variabel bebas pekerjaan $\left(\mathrm{X}_{1}\right)$ dan variabel tergantung lingkungan $(\mathrm{Z})$

Selanjutnya berdasarkan hasil perhitungan statistik uji $\mathrm{T}$ dari 2 variabel independen yang dimasukkan dalam model regresi ditemukan bahwa: 
1. Pendidikan $\left(\mathrm{X}_{1}\right)$ diperoleh nila thitung 2,754> $\mathrm{t}_{\text {tabel }} 1,986$ dan memilki nilai signifikan (sig) 0,007 pada tabel coefficients dengan nilai $\alpha$ (tingkat siginfikan) 0,05 . Artinya $0,007<0,05$. Dengan nilai ini memberikan makna bahwa secara parsial variabel Pendidikan $\left(\mathrm{X}_{2}\right)$ memberikan pengaruh secara siginfikan terhadap Kemiskinan rumah tangga (Y). Adapun besaran pengaruhnya dapat dilihat pada kolom Beta. Besaran pengaruh variabel $\mathrm{X}_{1}$ terhadap variabel $\mathrm{Y}$ yaitu $32,1 \%$.

2. Pekerjaan $\left(X_{2}\right)$ diperoleh nilai $t$ hitung $1,098<\mathrm{t}_{\text {tabel }} 1,986$ dan nilai signifikan (sig) 0,275 lebih besar dari nilai $\alpha 0,05$. Artinya $0,275>0,05$. Dengan nilai ini memberikan makna bahwa variabel pekerjaan $\left(\mathrm{X}_{1}\right)$ tidak memberikan pengaruh yang signifikan terhadap kemiskinan rumah tangga (Y). Adapun besaran pengaruhnya dapat dilihat pada kolom Beta. Besaran pengaruh variabel $\mathrm{X}_{1}$ terhadap variabel $\mathrm{Y}$ yaitu $12,8 \%$.

3. Variabel penelitian yang yang paling besar pengaruhnya terhadap kemiskinan rumah tangga di kecamatan Bolano kabupaten Parigi Moutong adalah variabel pendidikandengan besaran pengaruh yaitu $32,1 \%$

Dalam pengujian simultan diketahui bahwa variabel independen $(\mathrm{X})$ berpengaruh secara bersama-sama memberikan kontribusi secara signifikan terhadap variabel dependen. Berdasarkan hasil uji Anova (Analisis Of Varians), atau $\mathrm{F}$ tes diperoleh nilai $F_{\text {hitung }}$ sebesar 3,856 $>F_{\text {tabel }} 2.703$ dengan nilai Sig sebesar 0,025 lebih kecil dibandingkan alpha $(\alpha) \quad 0,05$. Dengan demikian hasil ini memberikan makna bahwa variabel pendidikan $\left(\mathrm{X}_{1}\right)$ dan Pekerjaan $\left(\mathrm{X}_{2}\right)$ secara simultan berpengaruh signifikan terhadap Kemiskinan rumah tangga (Y).

Analisis koefisien determinasi dilakukan untuk mengetahui seberapa besar persentase kontribusi independen terhadap variabel dependen (Y). Dari hasil perhitungan melalui alat ukur statistik SPSS 21 For Windows didapatkan nilai koefisien determinasi yaitu output SPSS Model Summary besarnya $\mathrm{R}^{2}$ adalah 0,077 , hal ini berarti bahwa variasi perubahan variabel kemiskinan rumah tangga (Y) dipengaruhi oleh perubahan variabel independen yang terdiri dari pendidikan $\left(\mathrm{X}_{1}\right)$, dan pekerjaan $\left(\mathrm{X}_{2}\right)$ sebesar $7,7 \%$. Sedangkan sisanya $(100 \%-7,7 \%=92,3 \%)$ jadi, $94,3 \%$ dipengaruhi oleh faktor lain yang tidak diteliti diluar dari penelitian ini.

\subsection{Pembahasan}

Berdasarkan hasil analisis uji regresi berganda dan uji residualdengan bantuan SPSS 21.0 for Windows pengaruh pendidikan dan pekerjaan terhadap kemiskinan rumah tangga dengan lingkungan sebagai variabel 
moderating di kecamatan Bolano kabupaten Parigi Moutong, menunjukkan bahwa secara simultan memiliki pengaruh positif terhadap kemiskinan rumah tangga. Begitu pula dengan pengaruh masing-masing variabel secara parsial masing-masing memiliki pengaruh dengan besaran pengaruh yang berbeda. Sedangkan secara residual bahwa variabel lingkungan tidak memoderasi hubungan antara pendidikan dan pekerjaan terhadap kemiskinan rumah tangga.

Berdasarkan hasil uji Anova (Analisis Of Varians), atau $\mathrm{F}$ tes diperoleh nilai $F_{\text {hitung }}$ sebesar 3,856> $F_{\text {tabel }} 2.703$ dengan nilai Sig sebesar 0,025 lebih kecil dibandingkan alpha $(\alpha)$ 0,05. Dengan demikian hasil ini memberikan makna bahwa variabel pendidikan $\left(\mathrm{X}_{1}\right)$ dan Pekerjaan $\left(\mathrm{X}_{2}\right)$ secara simultan berpengaruh signifikan terhadap Kemiskinan rumah tangga (Y).

a. Pengaruh pendidikan terhadap kemiskinan rumah tangga

Pendidikan dan kemiskinan pada kajian teori merupakan suatu lingkaran yang saling mempengaruhi. Disatu pihak, perubahan jenjang pendidikan mempengaruhi sekali perkembangan tingkat kemiskinan. dipihak lain, tingkat kemiskinan itu sendiri berpengaruh pula terhadap perkembangan pendidikan. ${ }^{56}$

Maka dari itu hasil penelitian menunjukkan bahwa pendidikan berpengaruh terhadap kemiskinan rumah tangga. hal ini juga tidak bertentangan dalam Islam karena pada dasarnya, pendidikan dalam Islam berupaya mengembangkan seluruh potensi peserta didik seoptimal mungkin, baik yang menyangkut aspek jasmani maupun rohaniah, akal dan akhlak. Dengan optimalisasi seluruh potensi yang dimilikinya, pendidikan Islam berupaya mengantarkan peserta didik kearah kedewasaan pribadi secara paripurna yaitu yang beriman dan berilmu pengetahuan.

Pengaruh pendidikan terhadap kemiskinan rumah tangga dapat dibuktikan berdasarkan hasil analisis regresi berganda yang menunjukkan bahwa variabel pendidikan berpengaruh terhadap kemiskinan rumah tanggan dan memiliki arah yang positif (+) terhadap kemiskinan rumah tangga dengan nilai konstanta 16.684 dan hasil koefisien sebesar 0,475 yang berarti jika terjadi peningkatan $1 \%$ pada pendidikan kepala rumah tangga maka tingkat kemiskinan rumah tangga akan meningkat sebesar $1 \%$, hal ini menunjukkan bahwa sekalipu terjadi peningkatan pendidikan kepala rumah tangga belum bisa

${ }^{56}$ Esmara Perencanaan, 377. 
menentukan suatu rumah tangga tingkat kemiskinannya akan menurun.

Berdasrkan pada uji $\mathrm{t}$ (parsial) diperoleh nila thitung $2,754>t_{\text {tabel }} 1,986$ dan memilki nilai signifikan (sig) 0,007 pada tabel coefficients dengan nilai $\alpha$ (tingkat siginfikan) 0,05 . Artinya $0,007<0,05$. Dengan nilai ini memberikan makna bahwa secara parsial variabel Pendidikan $\left(\mathrm{X}_{2}\right)$ memberikan pengaruh secara siginfikan terhadap Kemiskinan rumah tangga (Y). Adapun besaran pengaruhnya dapat dilihat pada kolom Beta. Besaran pengaruh variabel $\mathrm{X}_{1}$ terhadap variabel $\mathrm{Y}$ yaitu $32,1 \%$.

b. Pengaruh pekerjaan terhadap kemiskinan rumah tangga

Pekerjaan dalam arti sempit pekerjaan digunakan untuk suatu tugas / kerja yang menghasilkan uang bagi seseorang. ${ }^{57}$ Sedangkan dalam Islampekerjaan adalah bentuk dari pada kepatuhan beragama sekaligus jugamerupakan praktik ibadah.Maka umat Islam dikenakan kewajiban untuk bekerja seperti ibadah-ibadahlainnya.pekerjaan utama kepala rumah tangga sangat berpengaruh terhadap tingkat kemiskinan suatu rumah tangga, hal ini dikarenakan tiap jenis pekerjaan memiliki tingkat upah yang berbeda-beda.

Pengaruh pekerjaan terhadap kemiskinan rumah tangga dapat dibuktikan

\footnotetext{
${ }^{57}$ Lia Kurniawati dkk, Hubungan Antara, 4.
}

berdasarkan hasil analisis regresi berganda yang menunjukkan bahwa variabel pekerjaan berpengaruh terhadap kemiskinan rumah tanggan dan memiliki arah yang negatife (-) terhadap kemiskinan rumah tangga dengan nilai konstanta 16.684 dan hasil koefisien sebesar -0,282 yang berarti jika terjadi peningkatan $1 \%$ pada pekerjaankepala rumah tangga maka tingkat kemiskinan rumah tangga akan menurun sebesar $1 \%$, hal ini menunjukkan jika terjadi peningkatan jenis pekerjaan kepala rumah tangga maka tingkat upahnya pun akan meningkat, kesejahteraannya ikut meningkat dan kemiskinan rumah tangganya akan menurun. Berdasarkan pada uji $\mathrm{t}$ (parsial) diperoleh nilai $\mathrm{t}$ hitung $1,098<\mathrm{t}_{\text {tabel }}$ 1,986 dan nilai signifikan (sig) 0,275 lebih besar dari nilai $\alpha 0,05$. Artinya $0,275>0,05$. Dengan nilai ini memberikan makna bahwa variabel pekerjaan $\left(\mathrm{X}_{1}\right)$ tidak memberikan pengaruh yang signifikan terhadap kemiskinan rumah tangga (Y). Adapun besaran pengaruhnya dapat dilihat pada kolom Beta. Besaran pengaruh variabel $\mathrm{X}_{1}$ terhadap variabel $\mathrm{Y}$ yaitu $12,8 \%$.

Hasil penelitian ini sejalan dengan dianjurkannya bekerja dalam Islam, karena Islam memberkati pekerjaan dunia dan menjadikannya bagian ibadah dan jihad jika sang pekerja bersikap konsisten terhadap peraturan Allah, suci niatnya, dan tidak melupakan-Nya. Dengan bekerja individu 
bisa memenuhi kebutuhan hidupnya, mencukupi kebutuhan keluargannya, dan berbuat baik terhadap tetangganya. Demikian pula Dengan bekerja masyarakat bisa melaksanakan tugas kekhalifahannya, menjaga diri dari maksiat, dan meraih tujuan yang lebih besar. Semua bentuk yang diberkati agama ini hanya bisa terlaksana dengan memiliki harta dan mendapatkannya dengan bekerja.

c. Pengaruh pendidikan dan pekerjaan terhadap kemiskinan rumah tangga dengan lingkungan sebagai variabel moderating

Berdasarkan hasil analisis data secara residual tahap pertama, menunjukkan bahwa pendidikan (variabel bebas) dan lingkungan (variabel moderating) berpengaruh terhadap kemiskinan rumah tangga, dengan nilai konstanta 1,499 dan dilanjutkan nilai koefisien 0,62 yang hasilnya positif akan tetapi tidak signifikan maka lingkungan merupakan variabel moderating yang tidak memperlemah atau memperkuat antara variabel independen (pendidikan) dengan variabel dependen (kemiskinan rumah tangga). Sedangkan secara residual tahapkedua menunjukkan bahwa pekerjaan (variabel bebas) dan lingkungan (variabel moderating) berpengaruh terhadap kemiskinan rumah tangga, dengan nilai konstanta 0,661 dan dilanjutkan nilai koefisien 0,134 yang hasilnya positif akan tetapi tidak signifikan maka lingkungan merupakan variabel moderating yang tidak memperlemah atau memperkuat antara variabel independen (pekerjaan) dengan variabel dependen (kemiskinan rumah tangga).

Dari hasil penelitian tersebut dapat disimpulkan bahwa lingkungan bukanlah variabel moderating, akan tetapi hasil yang ditunjukkan tersebut tidak bertentangn dengan agam Islam, karena pada dasarnya agama Islam mendorong umat manusia untuk menjaga dan memelihara kesehatan karena faktor kesehatan lingkungan memepunyai pengaruh yang lebih besar terhadap derajat kesehatan.

Selain itu hasil usaha pemeliharaan kesehatan, tidak hanya terbatas pada terjadinya keadaan sehat, akan tetapi mempunyai dampak jauh lebih luas pada peningkatan makna hidup dan kehidupan itu sendiri baik perorangan maupun masyarakat, baik aspek duniawi maupun ukhrawi. Pemeliharaan kesehatan dengan segala aspeknya adalah amal kebajikan dari setiap amal kebajikan yang didasari iman dikategorikan amal saleh yang akan mendapat balasan berupa kehidupan yang lebih baik.

\section{Kesimpulan}

Berdasarkan hasil analisis data dan pembahasan bahwa secaraparsial variabel pendidikan $\left(\mathrm{X}_{2}\right)$ memeberikan pengaruh 
secara signifikan dan berhubungan positif (+) terhadap kemiskinan rumah tangga dengan besaran pengaruh pekerjaan yaitu $32,1 \%$.

Berdasarkan hasil analisis data dan pembahasan bahwa secara parsial variabel pekerjaan $\left(\mathrm{X}_{1}\right)$ tidak memeberikan pengaruh secara signifikan dan berhubungan negatif () terhadap kemiskinan rumah tangga dengan besaran pengaruh pekerjaan yaitu $12,8 \%$.

Adapun variabel dari pekerjaan dan pendidikan yang paling berpengaru terhadap kemiskinan rumah tangga adalah variabel pendidikan dengan besaran pengaruhnya yaitu $32,1 \%$.

Berdasarkan hasil analisis residual variabel lingkungan bukan variabel moderating yang memperkuat atau memperlemah antara variabel pekerjaan $\left(\mathrm{X}_{1}\right)$ terhadap rumah tangga miskin, hal ini dapat dilihat tabel koefisien yang bernilai positif yaitu 0,134 dan tidak signifikan karena nilai sig $0,195>0,05$.

Berdasarkan hasil analisis residual variabel lingkungan bukan variabel moderating yang memperkuat atau memperlemah antara variabel pendidikan $\left(\mathrm{X}_{2}\right)$ terhadap rumah tangga miskin, hal ini dapat dilihat tabel koefisien yang bernilai positif yaitu 0,134 dan tidak signifikan karena nilai sig $0,195>0,05$.

\section{Daftar Pustaka}

Beik, Syauqi Irfan dan Laily Dwi Arsyianti, Ekonomi Pembangunan Syariah. Jakarta: Raja Grafindo Persada, 2016.

Gozali, Imam, Aplikasi Analisis Multivariate Dengan Program IBM SPSS 21, Edisi ketujuh. Semarang : Badan penerbit Universitas Diponegoro, 2013.

Hamdi, saipul, Asep dan E Baharudidin, Metode Penelitian Kuantitatif Aplikasi Dalam Pendidikan. cet-ke I ; Yogyakarta : Deepulish, 2014.

Hasan, Alim, Zakat dan Infak:Salah Satu Solusi Mengatasi Problema Sosial di Indonesia. Jakarta : Kencana Perdana Media Group, 2006.

Hendra, Esmara, Perencanaan dan Pembangunan di Indonesia. Jakarta : PT. Gramedia, 1986.

Kementrian Agama Republik Indonesia, Alqur'an dan Terjemahnya. Surabaya : Pustaka Agung Harapan, 2011.

Khomas, Ali dkk, Indikator Kemiskinan dan Misklasifikasi Orang Miskin. Jakarta : Yayasan Pustaka Obor Indonesia, 2015.

Kuncoro, Mudrajat, Ekonomi Pembangunan : Teori, Masalah, dan Kebijakan,. Yogyakarta : AMP YKPN, 2010.

Misbah, Junaenah, Pendidikan Islam dalam Perspektif Teori dan Praktek. Jakarta 
Selatan : AMP Press Al-Mawardi Prima, 2016.

Mufroni, M. Arif, Akuntansi dan Manajemen Zakat. Kencana Perdana Media Group, 2001.

Oemar, Hamalik, Psikologi Belajar dan Mengajar. Bandung : Sinar Baru Algensindo, 2004.

Republik Indonesia, Undang-Undang No. 20 Tahun 2003, "Tentang Sistem Pendidikan Nasional".

Riduan, Penelitian Untuk Guru, Karyawan dan Penelitian Pemula. Bandung : Alfabeta, 2012.

Siregar, Syofian, Statistika Deskriptif Untuk Penelitian. Jakarta : Rajawali Pers, 2016.

Siregar, Syofian, Metode Penelitian Kuantitaif (dilengkapi dengan perbandingan perhitungan manual dan SPSS). Jakarta: Kencana, 2013.

Sugiyono, Metode penelitian kuantitatif kualitatif dan R\&D. cet k2-XXI ; Bandung : ALFABETA, 2014.

Statistic untuk penelitian, cet keXXII ; Bandung: Alfabeta, 2013.

, metode penelitian kuantitatif, kualitatif dan $R$ an $D$. cet. XXI ; Bandung : CV. Alfabeta, 2011.

Suharto, Edi, Kemiskinan \& Perlindungan Sosial Di Indonesia, Menggagas Model Jaminan Sosial Universitas Bidang Kesehatan. Bandung : Alfabeta, 2009.
Suliyanto, Ekonometrika Terapan, Teori dan Aplikasi Dengan SPSS. Yogyakarta : CV Andi, 2010.

Tafsir, Ahmad, Ilmu Pendidikan dalam Perspektif Islam. Bandung : PT Remaja Rosdakarya, 2011

Tjiptono, Pemasaran Jasa Prinsip, Penerapan, penelitian. Yogyakarta : penerbit ANDY, 2014.

\section{E-Jurnal}

Hermanto, Pengentasan Kemiskinan Di Pedesaan : Pengembangan SDM, Penguatan Usaha, Dan Inovasi Pertanian, Jurnal Penelitian Agro Ekonomi, Vol. 35 No. 2, (Desember 2017). https://www.researchgate.net>public ation. (Diakses 28 Desember 2018).

Jacobus, Elvira Handayani Elvira, Paulus Kindangen, Een $\mathrm{N}$ Walewangko, Analisis Faktor-Faktor Yang Mempengaruhi Kemiskinan Rumah Tangga Di Sulawesi Utara. Jurnal Pembangunan Ekonomi dan Keuangan Daerah, Vol. 19 No. 7. (Tahun 2018). https://ejournal.unsrat.ac.id>article >view. (Diakses 28 Desember 2018).

Juliandi, Parameter Prestasi Kerja dalamk Perspektif Islam. Jurnal Manajemen dan Bisnis, Vol. 14, No. 1, April 2014, 34-35. http://jurnal.umsu.ac.id. (Diakses Mei 2019).

Kurniawati, Lia dkk, Hubungan Antara Tingkat Pendidikan dan Status Pekerjaan dengan Usia Perkawinan Pertama Wanita Di Kelurahan Kotalama, Kec. Kedungkadang Kota 
Malang. Jurnal Preventia, Vol. 2 No. 1, (Tahun 2017). 4. http://journal.um.ac.id. (Diakses desember 2018).

Nurdin, N., Novia, N., Rahman, A., \& Suhada, R. (2019). Potensi Industri Produk Makanan Halal Di Kota Palu. Jurnal Ilmu Ekonomi dan Bisnis Islam, 1(1), 1-12.

Suryawati Criswardan, Memahami Kemiskinan Secara Multidimensional. Vol. 8 No. 03 (Tahun 2005), https://Jurnal.ugm.ac.id >article>view . (Diakses 28 Desember 2018).

Takdi Arif, Abubakar Hamzah dan Mohd. Nur Syechalad, Analisi Kemiskinan Rumah Tangga Berdasarkan Krakteristik Sosial Ekonomi Di Kabupaten Aceh Barat Daya, Jurnal Ilmu Ekonomi, Vol. 1, No. 4 (November 2013). www.jurnal.unsyiah.ac.id $>$ download. (Diakses 28 Desember 2018).

Wulandari, Roso Nike, Faktor-Faktor Yang Mempengaruhi Kemiskinan Rumah Tangga Di Kota Kendarai Tahun 2014, Jurnal Progres Ekonomi Pembangunan, Vol. 1 No. 1 (Tahun 2016).

https://edia.neliti.com>publication. (Diakses 28 Desember 2018).

Zafirah Hera Tengku, Pelaksanaan Penyelenggaraan Sanitasi Dasar Di Pasar Tradisional Peringan Di Kota Medan, $\quad 7-8 . \quad \mathrm{https}: / / \mathrm{m}$ - id.123dok.com. (Diakses Desember 2018).

\section{E-Skripsi}

Dewi, Sari Mulia, Ayula Candra, "Pengaruh Kepemilikan Aset, Pendidikkan, Pekerjaan, Dan Jumlah Tanggungan Terhadap Kemiskinan Rumah Tangga Di Kecamatan Bonang Kabupaten Demak”. Skripsi tidak diterbitkan. (Semarang : Jurusan Ilmu Ekonomi Studi Pembangunan Fakultas Ekonomika dan Bisnis UD Semarang, 2012).

Sa'Diyah, Yufi Halimah, “Analisis Kemiskinan Rumah Tangga Melalui Faktor-Faktor Yang Mempengaruhinya Di Kecamatan Tugu Kota Semarang". Skripsi tidak diterbitkan. (Semarang : Jurusan Ilmu Ekonomi dan Studi Pembangunan Fakultas Ekonomika dan Bisnis, 2012).

Iskandar, Yogi "Pengaruh Kesesuaian Kompensasi terhadap Kinerja Karyawan pada PT. Bentoel Distribusi Utama Cabang Palu" Skripsi tidak diterbitkan. (Palu : Jurusan Ekonomi Syariah Fakultas Syariah dan Ekonomi Islam 2017).

\section{Sumber Lain}

Dokumentasi, Rumah Tangga Miskin di Kabupaten Parigi Moutong Kecamatan Bolano, Desa April 2019. 